NEWS

\title{
Biosafety lab passes disaster test
}

\section{GALVESTON, TEXAS}

On 11 November, US officials will dedicate a new research complex containing highcontainment labs for deadly pathogens: the \$175-million Galveston National Laboratory in Texas. Yet even as questions arise over the safety of other biosecurity research facilities, the cornerstone of the new complex survived its biggest test yet: Hurricane Ike, which devastated Galveston Island last month yet left the new biosafety level 4 (BSL-4) lab intact.

The Galveston lab is one of several BSL- 4 facilities that have sprung up since the terrorist and anthrax attacks of 2001. Last week, the US Government Accountability Office released a scathing report on the security of the others. Two of the five current BSL-4 facilities, the report found, had security problems ranging from poor guard facilities to lax camera systems. Some members of Congress have called for the construction of new labs to be halted until such issues can be addressed. For now, the Galveston facility seems to be coming out the best - despite being located in a hurricane-prone zone.

Ike, which hit on 13 September, caused at least $\$ 700$ million worth of damage - including $\$ 275$ million in lost hospital revenues - to University of

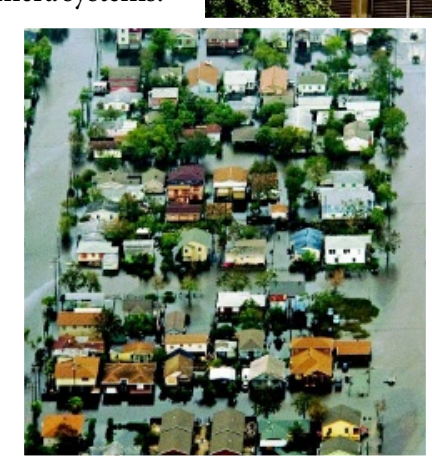

Flooding, not winds, caused most of the damage in Galveston - as did Tropical Storm Allison at research facilities in Houston, 75 kilometres north of Galveston, in 2001. Accordingly, at the new national laboratory in Galveston, the bottom two floors are built of sealed concrete, and a back-up power system - with a dedicated natural-gas line for fuel is located 11 metres above sea level. The new BSL-4 labs are on the top floors. Indeed, the new facility came in handy as staff rushed to fill its $-80^{\circ} \mathrm{C}$ freezers with research samples from elsewhere on campus before the storm hit. Other UTMB facilities, such as offices and wet labs, were built on lower, more vulnerable levels - mainly for cost reasons, says Stanley Lemon, director of the Institute for Human Infections and Immunity, the UTMB operation within the Galveston National Laboratory.

The university's current BSL-4 lab was safely positioned on the second floor of an older building. "We didn't lose the core," says Clarence Peters, the virologist who directs the UTMB's Center for Biodefense and Emerging Infectious Diseases. "If we had, it would be like

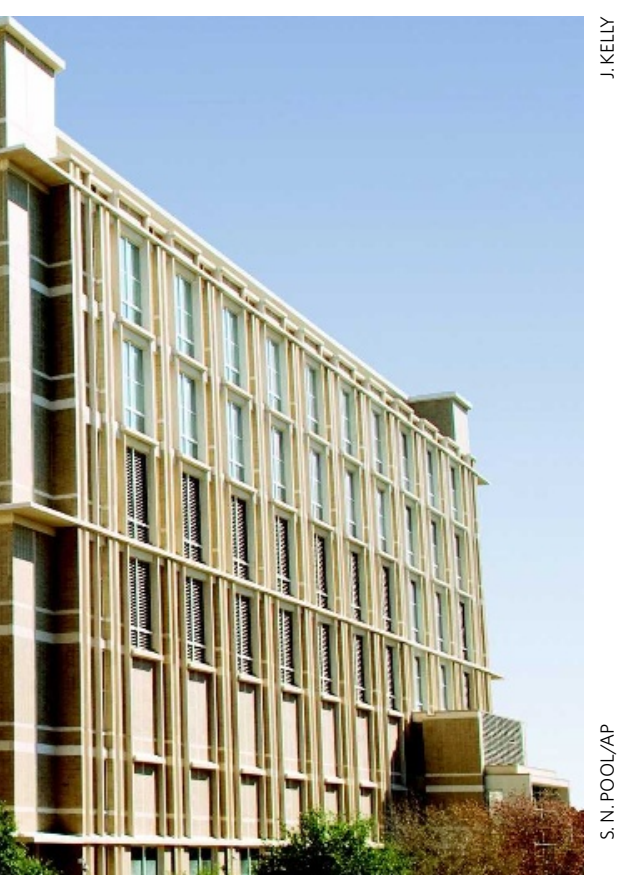

yas undamaged by the floods of Hurricane Ike.

starting all over again.” Still, he jokes: "I thought I was going to have to snorkel into my office." Located in the basement, it was waist-deep in water by the time he got there.

The vulnerability of BSL-4 labs is a hot topic in America these days. A second BSL-4 lab is under construction at Boston University in Massachusetts; its location, in South Boston, has triggered complaints from neighbourhood residents who worry about containment. Galveston, by comparison, is far less densely populated, and its history as a centre of tropical-disease research is more ingrained in the community.

The new lab at Galveston will be inaugurated with a lecture by Anthony Fauci, director of the National Institute of Allergy and Infectious Diseases in Bethesda, Maryland, which funded two-thirds of the facility's cost. It is meant to be certified and ready for operations this autumn.

Meanwhile, the federal government is to select by the end of the year a site for the \$450-million National Bio and Agro-Defense Facility, which will replace the Plum Island infectious-disease labs off New York. One of the five finalists is a low-rated site in Mississippi. It is inland, not immediately on the hurricaneprone Gulf Coast - but still is near the delta of the mighty Mississippi River.

Rex Dalton 